\title{
PENERAPAN METODE PEMBELAJARAN ROLE PLAYING UNTUK MENINGKATKAN HASIL BELAJAR PADA MATA PELAJARAN LAYANAN PORTER SISWA KELAS XI AKOMODASI PERHOTELAN 1 SMK PARIWISATA TRIATMAJAYA SINGARAJA
}

\author{
Kadek Meli Anggarsari, Ni Desak Made Sri Adnyawati, Cokorda Istri Raka Marsiti \\ Jurusan Pendidikan Kesejahteraan Keluarga \\ Universitas Pendidikan Ganesha \\ Singaraja, Indonesia \\ e-mail: \{Melianggarsarikadek@yahoo.com, sri.adnyawati@undiksha.ac.id , \\ raka.marsiti@undiksha.ac.id\}
}

\begin{abstract}
Abstrak
Penelitian ini bertujuan untuk (1) mendeskripsikan penerapan metode pembelajaran role playing untuk meningkatkan hasil belajar pada mata pelajaran layanan porter siswa kelas XI AP1 SMK Pariwisata Triatma Jaya Singaraja; (2) mendeskripsikan respon siswa kelas XI AP1 terhadap metode pembelajaran role playing dalam pembelajaran layanan porter. Alat pengumpulan data yang digunakan untuk hasil belajar pada ranah kognitif menggunakan tes tulis, ranah afektif menggunakan lembar observasi, dan ranah psikomotor menggunakan tes kinerja. Alat pengumpulan data yang digunakan untuk respon siswa adalah angket tertutup. Jenis penelitian ini adalah penelitian tindakan kelas. Hasil penelitian ini menunjukan bahwa (1) terjadi peningkatan hasil belajar dilihat dari analisis data pada siklus I yaitu rata-rata hasil belajar 83,6 dan ketuntasan hasil belajar 62,5\%. Pada siklus II yaitu rata-rata hasil belajar 87,0 dan ketuntasan hasil belajar $87,5 \%$. (2) respon siswa terhadap pembelajaran layanan porter dengan metode role playing pada siklus I sebesar 58,03 dan siklus II sebesar 64,18 yang terkategori positif.
\end{abstract}

Kata Kunci: hasil belajar, layanan porter, role playing

\begin{abstract}
This research ams to (1) Describe the application of learning method role playing to improve learning on the subject student porter service XI AP1 SMK Pariwisata Triatma Jaya Singaraja. (2) Describe student responses class XI Ap1 SMK Pariwisata Triatma Jaya Singaraja to method study role playing in learning service porter. Test was used in assessing cognitive domain, observation sheet was used in assessing affective domain, and psychomotor domain was assessed through practicing. Test the data collection tool used to respond student is aclosed questionnaire. Study was classroom action research. The result of this study shows that (1) there is an increase in learning outcomes seen from the analysis of the data on the cycle I was 83,6 and completeness of learning outcomes was $62,5 \%$ and in Cycle II average of learning outcomes was 87,0 and completeness of learning outcomes was $87,5 \%$. (2) Student response to porter service learning by method role playing in cycle I amount 58,03 and in cycle II was 64,18 which is category positive
\end{abstract}

Keywords: learning outcome, porter service, role playing 


\section{PENDAHULUAN}

Pendidikan merupakan rangkaian dari keseluruhan proses pembelajaran yang di dalamnya terdapat suatu aktivitas belajar dan pembelajaran yang dilakukan oleh siswa dan guru yang bertujuan untuk memperoleh ilmu pengetahuan. Kegiatan belajar disekolah merupakan kegiatan yang paling pokok sehingga banyak mengubah pola pikir pendidik dari pola pikir yang kaku menjadi lebih modern. Pembelajaran berlangsung sebagai suatu proses interaksi yang saling mempengaruhi antara guru dan siswa. Dalam kegiatan yang terjadi disekolah adalah guru mengajar dan siswa belajar.

Untuk dapat menyesuaikan diri dengan perubahan itu, pendidikan harus dapat berjalan seiring dengan perkembangan untuk mencapai keberhasilan pendidikan. Pada Kurikulum Tingkat Satuan Pendidik (KTSP) yang diterapkan di SMK Pariwisata Triatma Jaya Singaraja terdapat mata pelajaran produktif yaitu Menyediakan Layanan Porter untuk siswa yang mengambil konsentrasi Akomodoasi Perhotelan dikelas XI. Pada mata pelajaran ini terdapat 3 (tiga) Kompetensi Dasar yaitu Menangani barang bawaan tamu, Menangani kedatangan dan keberangkatan tamu dan merespon permintaan atas layanan bell desk. Pada kompetensi dasar menangani barang bawaan tamu terdapat 4 (empat) indikator yang harus dicapai oleh siswa yaitu (1) Menyebutkan tugas dan tanggung jawab porter, (2) menyebutkan perlengkapan yang diperlukan oleh seorang porter, (3) mengidentifikasi jenis-jenis barang bawaan tamu dan (4) Mendemonstrasikan pengisian formulir dan menumpuk barang bawaan diatas trolley.

Sedangkan untuk kompetensi dasar menangani kedatangan dan keberangkatan tamu terdapat 3 (tiga) indikator pencapaian siswa yaitu (1) menyebutkan prosedur penanganan

barang bawaan tamu check-in dan check-out, (2) menyebutkan prosedur penanganan barang bawaan tamu pindah kamar, rusak dan hilang, (3) mendemonstrasikan penanganan barang bawaan tamu check-in dan check-out. Untuk kompetensi dasar merespon permintaan atas layanan bell desk terdapat 3 (tiga) indikator yaitu (1) Menyebutkan jenis layanan bell desk, (2) menjelaskan prosedur setiap layanan bell desk yang disediakan, (3) mendemonstrasikan pelayanan bell desk.

Berdasarkan hasil observasi awal di SMK Pariwisata Triatma Jaya dengan salah satu guru yang mengajar pada mata pelajaran produktif menyediakan layanan porter menunjukan bahwa kemampuan dalam mengikuti pembelajaran masih kurang. Hal ini dapat dilihat dari pencapaian hasil belajar siswa yang belum mampu mencapai nilai KKM (Kriteria Ketuntasan Minumum) yang ditetapkan 85. Hal ini dapat dilihat dari nilai rata-rata siswa kelas XI Akomodasi Perhotelan 1 dimana jumlah siswa yang mencapai nilai KKM sebanyak 12 (36\%) siswa, dan yang belum mencapai nilai KKM 20 (64\%) siswa. (Leger Nilai Siswa Kelas XI Akomodasi Perhotelan 1 SMK Pariwisata Triatma Jaya Singaraja Tahun Ajaran 2016/2017).

Pembelajaran layanan porter adalah pembelajaran yang mengasah keterampilan siswa dalam berbahasa asing, selain itu sebagai bekal bagi siswa kelas XI yang akan melaksanakan praktik kerja industri atau training. Selama proses pembelajaran berlangsung metode yang digunakan guru dalam mengajar adalah metode ceramah dan demonstrasi. Setelah guru menjelaskan materi mengenai prosedur atau alur penanganan barang bawaan tamu check-in dan checkout, kemudian guru mendemonstrasikan prosedur tersebut didepan kelas dan menunjuk sebagian siswa yang bisa mengulangi prosedur yang dijelaskan oleh guru. Tanpa guru ketahui apakah siswa tersebut benar-benar menguasai materi dan memahami peran dari masing-masing siswa dalam prosedur penanganan barang bawaan tamu check-in dan check-out.

Berdasarkan pemaparan di atas, nampak bahwa perlunya upaya perbaikan proses belajar yang berpusat pada siswa dan lebih banyak melibatkan siswa dalam subyek belajar. Sehingga nantinya dapat 
meningkatkan pengetahuan dan keterampilan pada saat praktik penanganan barang bawaan tamu checkin dan check-out. Metode pembelajaran yang inovatif perlu dikembangkan untuk menghadapi masalah yang terjadi yaitu menekankan pada interaksi siswa untuk saling memotivasi dan saling membantu dalam menguasai materi pelajaran guna mencapai hasil belajar yang maksimal. Salah satu metode pembelajaran yang dapat membantu mengatasi permasalahan yang timbul dengan Metode Pembelajaran Role Playing.

Metode Role Playing adalah salah satu bentuk permainan pendidikan yang dipakai untuk menjelaskan peranan, tingkah laku, dan nilai dengan tujuan menghayati perasaan, sudut pandang dan cara berpikir orang lain Husein Achmad (Hidayati, 2004: 93). Role Playing atau bermain peran merupakan metode pembelajaran sebagai bagian dari simulasi yang diarahkan untuk mengkreasi peristiwa-peristiwa aktual atau kejadiankejadian yang mungkin muncul pada masa mendatang. Didalam bermain peran, guru menerima peran noninterpersonal didalam kelas. Siswa menerima karakter, perasaan, perasaan dan ide-ide orang lain dalam suatu situasi yang khusus.

Beberapa penelitian yang telah dilakukan bahwa penerapan metode pembelajaran Role Playing dapat meningkatkan KKM siswa dalam pembelajaran diantaranya peneliti yang dilakukan oleh Ketut Jasiani pada tahun 2015 bahwa dengan metode role playing pada mata pelajaran IPS siswa menjadi termotivasi untuk belajar lebih giat dan rajin lagi sehingga terjadi peningkatan hasil belajar. Selain itu I Kadek Parmadi 2015 juga menunjukan bahwa Penerapan Metode Pembelajaran Role Playing dapat meningkatkan kualitas proses pembelajaran dan hasil belajar siswa yang mencapai KKM dalam pembelajaran Sejarah Indonesia.

Berdasarkan dari uraian di atas maka peneliti ingin melakukan penelitian dengan judul Penerapan Metode Pembelajaran Role Playing Untuk Meningkatkan Hasil Belajar Pada Mata Pelajaran Layanan Porter Siswa Kelas XI
Akomodasi Perhotelan 1 SMK Pariwisata Triatma Jaya Singaraja.

\section{METODE}

Penelitian ini merupakan penelitian tindakan kelas (PTK) yang bertujuan untuk memecahkan permasalahan yang nyata terjadi di kelas dan meningkatkan kegiatan nyata guru dalam pengembangan profesinya. Penelitian tindakan kelas ini dilaksanakan dengan tahapan sebagai berikut : perencanaan, pelaksanaan, observasi serta refleksi secara berulang.

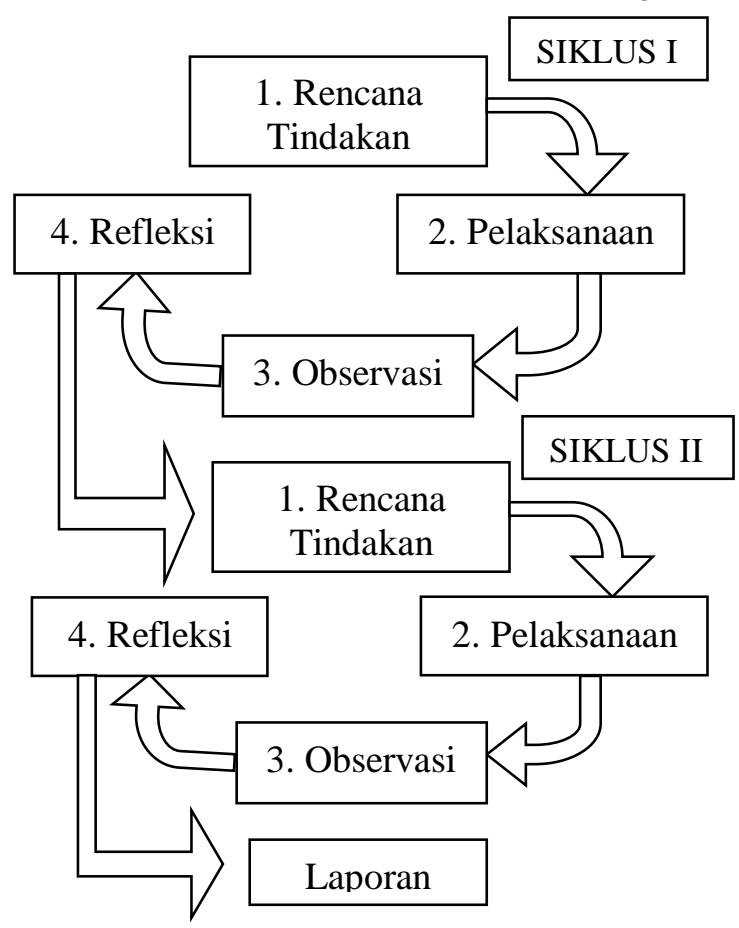

Gambar 1. Prosedur Penelitian Tindakan Kelas (Prof. Dr. H.E Mulyasa, M.Pd : 2009)

Berdasarkan hasil observasi awal yang dilakukan oleh peneliti, maka dalam hal ini untuk mengatasi permasalahan dalam proses pembelajaran tersebut, maka peneliti mengajukan solusi yaitu penerapan metode pembelajaran role playing untuk meningkatkan hasil belajar pada mata pelajaran layanan porter siswa kelas XI Akomodasi Perhotelan 1 SMK Pariwisata Triatma Jaya Singaraja. Yang dimulai dari tahap perencanaan yaitu : a. Mensosialisasikan pada guru mata pelajaran Layanan Porter kelas XI Akomodasi Perhotelan 1 di SMK Pariwisata Triatma Jaya Singaraja 
mengenai pelaksanaan penelitian yang akan dilaksanakan di kelas XI Akomodasi Perhotelan 1 dalam pembelajaran menyediakan layanan porter dengan metode role playing, b. Kompetensi dasar yang akan dibahas menangani kedatangan dan keberangkatan tamu. Dengan materi prosedure penanganan barang bawaan tamu check-in dan checkout, c. Peneliti berkalaborasi dengan guru menyiapkan skenario dan instrumen pembelajaran. Menyusun RPP yang sesuai dengan kompetensi Dasar menangani kedatangan dan keberangkatan tamu Menyiapkan pretest (tes awal) dan posttest (tes akhir) pembelajaran Menyiapkan Instrumen berupa lembar observasi penilaian afektif, tes kognitif dan tes unjuk kerja yang ini digunakan untuk mengetahui hasil belajar siswa Menyusun angket respon siswa

Pelaksanaan tindakan pada siklus I dilaksanakan dalam 3 kali pertemuan. Materi yang dibahas adalah prosedur penanganan kedatangan dan barang bawaan tamu check-in perorangan, rombongan (group). Pada siklus I pertemuan pertama Guru menjelaskan tujuan pembelajaran, latar belakang, manfaat yang ingin dicapai dalam pelajaran layanan porter pada materi prosedurpenanganan barang bawaan tamu check-in. Pada pertemuan ini guru akan menjelaskan bagaimana prosedur mengenai penanganan kedatangan dan barang bawaan tamu individual, rombongan/ group check in. Kemudian guru meminta siswa membentuk kelompok yang masing-masing beranggotakan 3 orang/siswa dan memainkan peran sebagai doorman,bellboy/bellman, dan guest. Masing-masing kelompok harus mempersiapkan percakapan mengenai prosedur penanganan barang bawaan tamu check-in dalam bahasa inggris.

Pada siklus I pertemuan kedua siswa mempraktikan prosedur penanganan barang bawaan tamu check-in individual bersama anggota kelompoknya di depan kelas dan guru melakukan penilaian ujian praktek. Pada siklus I pertemuan ketiga guru memberikan tes akhir untuk mengetahui kemampuan siswa terhadap materi dan hasil belajar siswa. Tahap selanjutnya adalah Observasi I yaitu dengan melakukan evaluasi dan siklus I diakhiri dengan tes tulis untuk mengetahui tingkat pengetahuan siswa terhadap prosedur kedatangan barang bawaan tamu. Refleksi Pada akhir siklus I, peneliti melakukan refleksi terhadap pelaksanaan pembelajaran selama proses pembelajaran berlangsung. Refleksi dilakukan berdasarkan hasil observasi/evaluasi selama proses pembelajaran. Pada tahap ini peneliti mengkaji kekurangan dan hambatan yang dialami dari tindakan yang telah diberikan untuk dijadikan pertimbangan dalam merancang dan melaksakan tindakan pada siklus berikutnya.

Perencanaan pada siklus II ini didasarkan pada hasil refleksi siklus I, akhir setiap siklus oleh peneliti bersama guru dengan tujuan melihat kelemahankelemahan dan kelebihan yang terjadi dalam tindakan pada siklus I dan memberikan masukan tindakan dalam siklus II. Serta melihat kelemahan pada siklus I untuk dapat diperbaiki pada siklus II. Tahap perencanaan tindakan II dengan menyiapkan materi ajar mengenai prosedur penanganan barang bawaan tamu check-out, menyiapkan skenario serta instrumen pembelajaran.

Pelaksanaan Tindakan II Pada siklus II pertemuan pertama guru akan menjelaskan materi mengenai prosedure keberangkatan dan barang bawaan tamu (check-out) individual dan rombongan. Guru menjelaskan hal-hal mengenai bagaimana prosedur dari keberangkatan tamu dan barang bawaannya. Kemudian guru akan membagi siswa menjadi 3 orang/siswa yang akan memainkan peran doorman, bellboy dan guest dan mempersiapkan percakapan keberangkatan tamu dan barang bawaan tamu. Pada siklus II pertemuan kedua siswa mempraktikan prosedur keberangkatan dan barang bawaan tamu individual (check-out) bersama anggota kelompoknya di depan kelas dan guru melakukan penilaian ujian praktik. Pada siklus II pertemuan ketiga guru memberikan tes akhir untuk mengetahui kemampuan dan hasil belajar siswa. 
Tahap Observasi II melakukan evaluasi dan siklus II diakhiri dengan tes tulis untuk mengetahui peningkatan hasil belajar siswa. Refleksi pada siklus II, dilakukan setiap akhir siklus. Dasar refleksi di akhir siklus II adalah perubahan hasil belajar terhadap pembelajaran yang telah berlangsung. Hasil refleksi pada siklus II merupakan rekomendasi untuk saran tindakan.

Penelitian ini dilaksanakan pada siswa kelas XI Akomodasi Perhotelan bertempat di SMK Pariwisata Triatma Jaya Singaraja dalam mata pelajaran Menyediakan Layanan Porter. Penelitian dilaksanakan pada semester kedua (genap) tahun ajaran 2016/2017. Subjek penelitian tindakan kelas ini adalah siswa kelas XI Akomodasi Perhotelan 1 semester genap SMK Pariwisata Triatma Jaya Singaraja tahun pelajaran 2016/2017. Sedangkan untuk objek dari penelitian ini adalah hasil belajar, respon siswa terhadap metode pembelajaran Role Playing.

Data yang dikumpulkan dalam penelitian ini adalah data tentang hasil belajar siswa dan respon siswa dalam menangani kedatangan dan keberangkatan tamu kelas XI AP1 SMK Pariwisata Triatma Jaya Singaraja. Metode yang digunakan adalah metode Observasi dan Tes. Metode Observasi digunakan untuk menilai ranah afektif dalam hasil belajar siswa. Teknik tes digunakan untuk megukur ranah kognitif (pengetahuan) atau pemahaman siswa mengenai materi prosedur menangani kedatangan dan keberangkatan tamu. Teknik tes kinerja digunakan untuk mengetahui ada tidaknya peningkatan kemampuan / kompetensi siswa dalam kompetensi dasar menangani kedatangan dan keberangkatan tamu pada mata pelajaran layanan porter sesudah diterapkan treatment. Setelah data terkumpul kemudian dilakukan analisis data. Teknik analisis data yang digunakan pada penelitian ini yaitu mengunakan metode analisis deskriptif kuantitatif. Metode analisis deskriptif kuantitatif adalah suatu cara pengolahan data yang dilakukan dengan jalan menyusun secara sistematis dalam bentuk angka-angka dan atau persentase mengenai keadaan suatu objek yang diteliti sehingga diperoleh kesimpulan umum.

Data tentang hasil belajar siswa dianalisis secara deskriptif kuantitatif, sedangkan kualifikasi hasil belajar siswa dikatakan berhasil apabila siswa telah mampu memenuhi Kriteria Ketuntasan Minimum (KKM) yaitu 85 yang diperoleh berdasarkan pedoman konversi yang dikutip dari raport siswa SMK Pariwisata Triatma Jaya Singaraja tahun ajaran 2016/2017. Sudjana (2004:22) menyatakan bahwa hasil belajar adalah"kemampuan-kemampuan yang dimiliki siswa setelah ia menerima pengalaman belajarnya". Hasil belajar siswa dinilai dari perubahan tingkah laku, menyangkupaspek kognitif, afektif, dan psikomotor yang dapat dikuasai siswa setelah menerima pembelajaran.

Data respon siswa dikumpulkan dengan menggunakan angket. Instrumen yang digunakan adalah koesioner/angket model Likert. Untuk mengetahui respon siswa data yang didapat melalui kuisioner atau angket tanggapan siswa. Angket ini menggunakan skala Likert dengan pilihan Sangat Setuju (SS), Setuju (S), Ragu-ragu (R), Tidak Setuju (TS), dan Sangat Tidak Setuju (STS).Skor rata-ratarespon siswa yang dianalisis dengan rumus sebagai berikut.

$$
\bar{X}=\frac{\sum X}{\mathrm{~N}}
$$

Keterangan :

$\bar{X} \quad=$ Skor rata-rata tanggapan/respon siswa

$\sum X=$ jumlah seluruh skor

$\mathrm{N}=$ jumlah siswa

$\mathrm{MI}=1 / 2$ (skor tertinggi ideal + skor terendah ideal)

SDI $=1 / 6$ (skor tertinggi ideal + skor terendah ideal.

Pemberian skor untuk setiap item pernyataan respon siswa. 
Tabel 1

Kriteria Penggolongan Respon Siswa

\begin{tabular}{|l|l|}
\hline \multicolumn{1}{|c|}{ Kriteria } & \multicolumn{1}{|c|}{ Kategori } \\
\hline $\mathrm{Ml}+1,5 \mathrm{SDI} \leq \bar{X}$ & Sangat Positif \\
\hline $\mathrm{Ml}+0,5 \mathrm{SDI}<\bar{X}<\mathrm{Ml}+1,6 \mathrm{SDI}$ & Positif \\
\hline $\mathrm{Ml}-0,5 \mathrm{SDI} \leq \bar{X}<\mathrm{Ml}+0,5 \mathrm{SDI}$ & Kurang positif \\
\hline $\mathrm{Ml}-1,5 \mathrm{SDI} \leq \bar{X}<\mathrm{Ml}-0,5 \mathrm{SDI}$ & Negatif \\
\hline $\bar{X}<\mathrm{Ml}-1,5 \mathrm{SDI}$ & Sangat Negatif \\
\hline
\end{tabular}

(Nurkancana dan Sunartana, 1992:102)

\section{HASIL DAN PEMBAHASAN}

Hasil penelitian tindakan kelas ini dilaksanakan di kelas XI Akomodasi Perhotelan 1 SMK Pariwisata Triatma Jaya Singaraja dengan jumlah siswa 32 orang yang terdiri dari 19 siswa laki-laki dan 13 siswa perempuan. Penelitian tindakan kelas ini dilakukan dalam dua siklus, pada siklus pertama terdiri dari tiga pertemuan yaitu, pada pertemuan pertama ditujukan untuk pendalaman materi dan penilaian afektif, pada pertemuan kedua ditujukan untuk melakukan praktikum untuk penilaian psikomotor, dan pertemuan ketiga dilakukan evaluasi untuk penilaian kognitif. Pada siklus kedua terdiri dari tiga pertemuan yaitu, pada pertemuan pertama ditujukan untuk pendalaman materi dan penilaian afektif, pada pertemuan kedua ditujukan untuk melakukan praktikum untuk penilaian psikomotor, dan pertemuan ketiga dilakukan evaluasi untuk penilaian kognitif. Alokasi waktu untuk masing-masing pertemuan adalah dua jam pelajaran. Satu jam pelajaran sama dengan empat puluh lima menit.

Data yang dikumpulkan dalam penelitian tindakan kelas ini adalah data mengenai hasil belajar dan respon siwa pada mata pelajaran Layanan Porter dengan materi prosedur penanganan dan barang bawaan tamu tiba dan berangkat, menggunakan metode pembelajaran Role Playing. Data-data yang diperoleh, kemudian dikumpulkan dan dianalisis sesuai dengan teknik analisis data yang telah ditentukan. Berikut analisis data hasil belajar siswa mata pelajaran Layanan Porter.

Pelaksanaan Tindakan Siklus I Pertemuan pertama dilaksanakan pada hari selasa, tanggal 7 Maret 2017. Kegiatan yang dilakukan adalah pemberian materi prosedur penanganan barang bawaan tamu check in. Pada pertemuan ini peneliti menerapkan metode pembelajaran role playing yang dilaksanakan sesuai dengan RPP yang telah dirancang. Pada pertemuan kedua ini dilaksanakan pada hari selasa, tanggal 14 Maret 2017. Kegiatan yang dilakukan adalah praktik prosedur barang bawaan tamu check in dengan menerapkan metode pembelajaran role playing yang dilaksanakan sesuai dengan RPP yang telah dirancang. Pada pertemuan III ini dilaksanakan pada 21 Maret 2017. Adapun kegiatan pada pertemuan III ini adalah mengisi kuisioner dan menjawab tes evaluasi pertemuan I dan pertemuan II. Pada tahap observasi digunakan untuk menilai sikap siswa pada saat mengikuti proses pembelajaran berlangsung yang sebelumnya telah dibuat sebuah lembar observasi berdasarkan indikator yang telah ditentukan oleh sekolah.Pada akhir siklus I diadakan tes evaluasi untuk mengetahui hasil dari pembelajaran siklus I. Bentuk tes yang diberikan adalah tes uraian dengan jumlah soal 5 butir dan alokasi waktu 2 x 45 menit.

Dari hasil observasi yang laksanakan pada saat proes pembelajaran sikus I, dapat disimpulkan beberapa hal diantaranya: Pada aspek kognitif, masih kurangnya pemahaman siswa mengenai 
materi prosedur penanganan kedatangan dan barang bawaan tamu, hal ini terlihat dari masih rendahnya nilai yang diperoleh dari hasil tes tulis siswa. Pada saat praktik masih terdapat kesalahan dalam melakukan prosedur penanganan kedatangan dan barang bawaan tamu, siswa masih ragu-ragu dalam melakukan prosedur penangan kedatangan dan barang bawaan tamu, contoh : siswa masih melihat naskah yang telah dibuat bersama anggota kelompoknya, siswa masih belum bersungguh-sungguh melakukan prosedur penanganan dan barang bawaan tamu sesuai dengan perannya sebagai petugas bellboy dan tam

Tabel 2

Data Hasil Belajar Siklus I

\begin{tabular}{|c|c|c|c|c|c|c|c|}
\hline \multicolumn{8}{|c|}{ Nilai Hasil Belajar Siklus II } \\
\cline { 1 - 4 } Kognitif & Afektif & Psikomotor & Jumlah & $\begin{array}{c}\text { Rata- } \\
\text { rata }\end{array}$ & KKM & KK & KK Yang Dicapai \\
\hline 81,71 & 84,79 & 84,21 & 2674,5 & 83,6 & 85 & $85 \%$ & 62,5 \\
\hline
\end{tabular}

Dari hasil pelaksanaan tindakan siklus I dapat dilihat bahwa rata-rata nilai kognitif sebesar 81,71, afektif 84,79 dan psikomotor 84,21 . Setelah nilai kognitif, afektif dan psikomotor dijumlahkan dan dirata-ratakan maka didapat nilai hasil belajar siswa pada siklus I dengan nilai total sebesar 2674,5 dan rata-rata 83,6 dengan persentase ketuntasan klasikal sebesar $62,5 \%$.

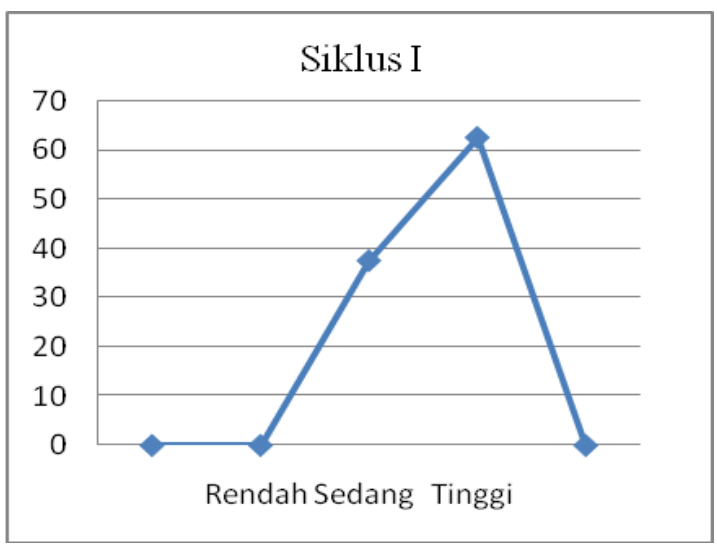

Gambar 2. Kategori Hasil Belajar Siklus I

Karena hasil analisis data dari Siklus I belum mencapai indikator keberhasilan yang ditetapkan maka dapat dikatakan bahwa pembelajaran Layanan Porter pada Siklus I belum tuntas sehingga perlu diadakan perbaikan pada siklus selanjutnya yaitu Siklus II.

Pada hasil observasi dan evaluasi siklus I menunjukan bahwa, dalam hal sikap siswa pada saat mengikuti pembelajaran sudah cukup baik namun masih ada beberapa siswa yang kurang fokus pada saat pemberian materi ajar dan saat praktikum ada beberapa siswa yang kurang aktif, terutama para siswa laki-laki. Sedangkan hasil belajar siswa pada siklus I masih belum mencapai ketuntasan klasikal yang ditentukan. Belum tercapainya ketuntasan hasil belajar pada siklus I dikarenakan siswa masih kurang terbisa dengan penerapan metode pembelajaran role playing. Sehingga perlu ditumbuhkan kesadaran pada siswa dalam proses pembelajaran. Dari hasil refleksi tersebut, peneliti dipandang perlu melanjutkan ke siklus II untuk memperbaiki hasil yang diperoleh pada siklus I. Upaya yang dilakukan untuk menyelesaikan masalah yang terjadi pada sikus I antara lain: Untuk meningkatkan pemahaman siswa terhadap materi peneliti harus lebih aktif dan tanggap memberikan peringatan kepada siswa yang kurang aktif dan fokus dalam mengikuti proses pembelajaran dengan memberikan sebuah pertanyaan kepada siswa tersebut.

Untuk meningkatkan pemahaman siswa tentang Metode Pembelajaran Role Playing yang diterapkan, peneliti memberikan gambaran umum mengenai materi yang akan dibahas pada pertemuan yang akan datang, agar siswa 
dapat mempelajarinya terlebih dahulu di rumah masing-masing. Pertemuan I Pada Siklus II. Untuk pertemuan pertama pada siklus II ini dilaksanakan pada hari selasa, tanggal 11 April 2017. Kegiatan yang dilakukan pada pertemuan pertama di siklus II ini adalah pemberian materi prosedur barang bawaan tamu check out dengan menerapkan metode pembelajaran role playing sesuai dengan RPP yang sudah dirancang.

Untuk pertemuan kedua pada siklus II ini dilaksanakan pada hari selasa, tanggal 18 April 2017. Kegiatan yang dilakukan adalah praktik mengenai prosedur penanganan barang bawaan tamu check out dengan menerapkan metode pembelajaran role playing sesuai dengan RPP yang sudah dirancang. Pada pertemuan III ini dilaksanakan pada 25 April 2017. Adapun kegiatan pada pertemuan III ini adalah mengisi kuisioner dan menjawab tes evaluasi pertemuan I dan pertemuan II Pada saat observasi digunakan untuk penilaian sikap siswa pada saat proses pembelajaran berlangsung yang sebelumnya telah dibuat sebuah lembar observasi berdasarkan indikator yang telah ditentukan oleh sekolah. Pada akhir siklus II diadakan tes evaluasi untuk mengetahui hasil dari pembelajaran siklus II.

Bentuk tes yang diberikan adalah tes essay dengan jumlah soal 5 butir dan alokasi waktu 2 x 45 menit. Berdasarkan hasil observasi yang dilakukan pada saat proes pembelajaran sikus II, dapat disimpulkan beberapa hal diantaranya: Pada saat pemberian materi masih ada beberapa siswa yang kurang fokus dalam mengikuti pelajaran tetapi sudah berkurang dibandingkan pada siklus I sebelumnya. Pada saat praktikum masih ada beberapa siswa yang kurang aktif tetapi sudah berkurang dibandingkan dengan siklus I.

Tabel 3.

Data Hasil Belajar Siklus II

\begin{tabular}{|c|c|c|c|c|c|c|c|}
\hline \multicolumn{7}{|c|}{ Nilai Hasil Belajar Siklus II } \\
\cline { 1 - 4 } Kognitif & Afektif & Psikomotor & Jumlah & Rata-rata & KKM & KK & $\begin{array}{c}\text { KK } \\
\text { Yang } \\
\text { Dicapai }\end{array}$ \\
\hline 88,12 & 85,73 & 87,18 & 2784,5 & 87,0 & 85 & $85 \%$ & $87,5 \%$ \\
\hline
\end{tabular}

Dari hasil pelaksanaan tindakan siklus II dapat dilihat bahwa rata-rata nilai kognitif sebesar 88,12, afektif 85,73 dan psikomotor 87,18. Setelah nilai kognitif, afektif dan psikomotor dijumlahkan dan dirata-ratakan maka didapat nilai hasil belajar siswa pada siklus II dengan nilai total sebesar 2784,5 dan rata-rata 87,0 yang masuk dalam kategori tinggi.

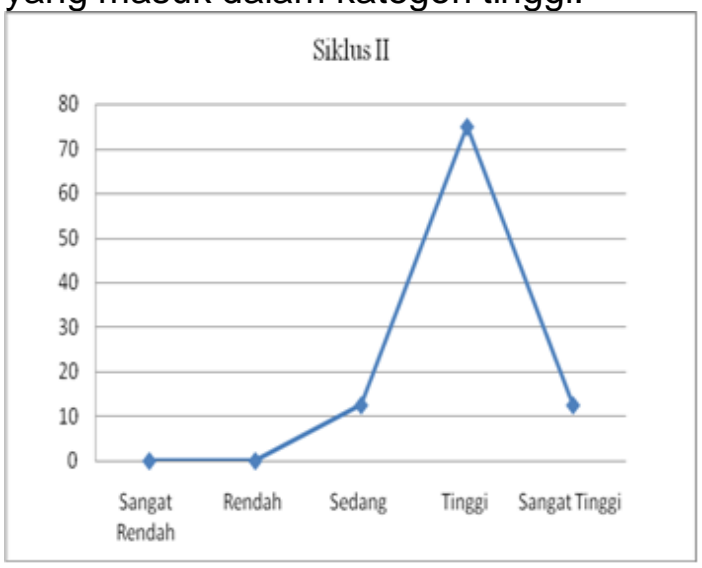

Gambar 3. Kategori Hasil Belajar Siklus II

Dari 32 siswa terdapat 4 siswa yang memperoleh hasil belajar dalam kategori sangat tinggi, 24 siswa dalam kategori tinggi dan 4 siswa dalam kategori sedang. Dari rata-rata hasil belajar siswa yang diperoleh pada siklus II maka hasil belajar tersebut masuk dalam kategori tinggi. Untuk ketuntasan klasikal yang diperoleh yaitu $87,5 \%$ sehingga hasil belajar yang diinginkan dapat dikatakan tercapai.

Dari penjelasan diatas secara umum telah mampu menjawab rumusan masalah dan mencapai tujuan yang diharapkan peneliti. Penelitian ini dapat dikatakan berhasil karena semua kriteria yang ditentukan telah terpenuhi. $\mathrm{Hal}$ ini menandakan bahwa dengan penerapan metode pembelajaran Role Playing dapat meningkatkan hasil belajar Layanan Porter 
siswa kelas XI Akomodasi Perhotelan 1 semester genap tahun ajaran 2016/2017.

Dari hasil observasi dan evaluasi siklus II menunjukan bahwa, sikap siswa pada saat mengikuti proses pembelajaran sudah baik tetapi masih ada beberapa siswa yang kurang fokus pada saat pemberian materi, saat melaksanakan pembelajaran masih ada beberapa siswa yang kurang aktif, terutama para siswa laki-laki, tetapi jumlahnya sudah berkurang dibandingkan pada siklus I. Sedangkan untuk hasil belajar siswa pada siklus II sudah mencapai ketuntasan klasikal yang ditentukan yakni diatas $85 \%$. Dengan tercapainya semua kriteria yang telah ditentukan sebelumnya, maka penelitian tindakan kelas ini dihentikan.

Data respon siswa mengenai metode Role Playing pada mata pelajaran Layanan porter disebarkan dengan angket respon siswa sebanyak 15 pertanyaan yang terdiri dari pertanyaan positif. Setiap pertanyaan skor maksimal 5 dan minimal 1 , sehingga diperoleh skor tertinggi 75 dan skor terendah 15.

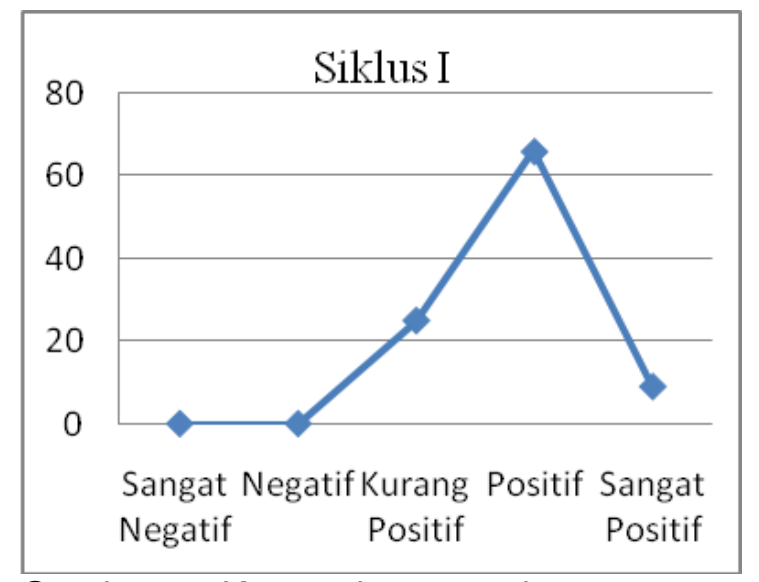

Gambar 4. Kategori respon siswa terhadap metode role playing Siklus I

Dapat disimpulkan bahwa (1) terdapat 3 orang siswa merespon sangat positif (9\%); (2) siswa yang merespon positif sebanyak 21 orang (66\%); (3) Siswa yang merespon kurang positif sebanyak 8 orang (25\%); (4) tidak ada siswa merespon negatif dan sangat negatif.

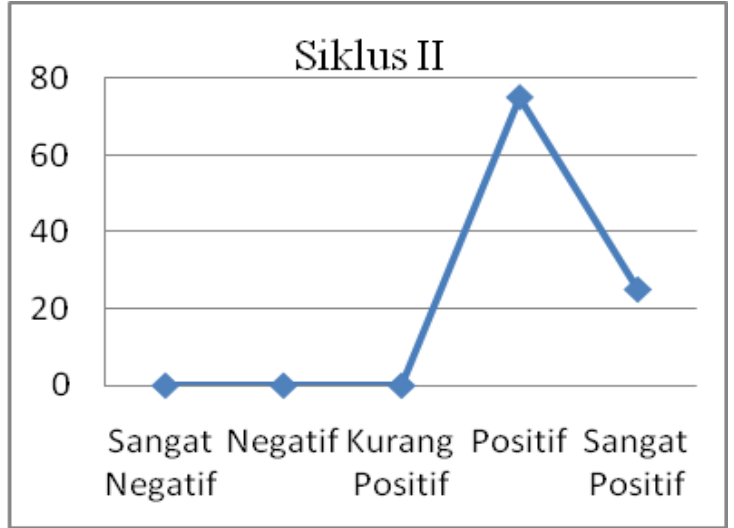

Gambar 5. Kategori respon siswa terhadap metode role playing Siklus II

Respon siswa terhadap metode role playing pada siklus II dapat disimpulkan bahwa (1) terdapat 8 orang siswa merespon sangat positif (25\%); (2) siswa yang merespon positif sebanyak 24 orang (75\%); (3) tidak ada siswa merespon negatif dan sangat negatif. Terjadi peningkatan respon siswa pada siklus II yaitu rata-rata sebesar $2054(64,18)$. Jika dilihat berdasarkan criteria penggolongan respon siswa berada pada rentangan 52,5 $\leq \bar{X}<67,5$ atau berada pada kategori positif.

\section{PEMBAHASAN}

Pada pelaksanaan siklus I dilakukan dalam 3 kali pertemuan, yaitu 1 kali pertemuan dalam proses pembelajaran, yang saat itu dilakukan penilaian aspek afektif, 1 kali pertemuan untuk praktikum (aspek psikomotor) dan 1 kali pertemuan untuk tes hasil belajar (aspek kognitif) siswa pada akhir siklus. Pada pelaksanaan siklus II dilaksanakan dalam 3 kali pertemuan, 1 kali pertemuan dalam proses pembelajaran, pada saat itu dilakukan penilaian aspek afektif, 1 kali pertemuan untuk praktikum dan 1 kali pertemuan untuk tes hasil belajar (aspek kognitif) siswa pada akhir siklus. Alokasi waktu untuk setiap pertemuan adalah sembilan puluh menit.

Data hasil belajar siswa pada siklus I menunjukan bahwa terdapat 20 siswa $(62,5)$ yang sudah mampu memenuhi KKM dan 12 siswa $(37,5)$ belum mampu memenuhi KKM. Rata-rata hasil belajar 
siswa pada siklus I diperoleh sebesar 83,6 dengan ketuntasan klasikal sebesar $62,5 \%$. Dari analisis hasil belajar pada siklus I ditemukan beberapa permasalahan yaitu :Proses pembelajaran pada siklus I secara umum belum dapat berjalan secara maksimal sesuai dengan rencana yang telah disusun. Hal ini terjadi karena siswa belum terbiasa dengan metode yang digunakan yaitu metode role playing. Siswa masih cenderung menggunakan metode lama yaitu metode demonstrasi, dimana siswa secara keseluruhan belum mampu mempraktikan prosedur penanganan kedatangan dan barang bawaan tamu dan ragu bertanya kepada guru. Karena keterbatasan waktu dikarenakan siswa belum mampu menguasai praktik dan masih membaca skenario atau percakapan yang telah dibuat sebelumnya sehingga peneliti bersama guru masih memberikan bimbingan dan arahan kepada siswa. Dengan memahami kendala-kendala dalam permasalahan tersebut, maka dilakukan beberapa upaya perbaikan untuk mengatasi kendala dan permasalahan yang terjadi dengan melakukan beberapa tindakan sebagai berikut : Sebelum melaksanakan tindakan pada siklus II, siswa diarahkan dan dituntun kembali mengenai proses pembelajaran yang diterapkan agar pada saat praktik berjalan dengan hasil yang diharapkan. Guru hanya berperan sebagai fasilitator dan mediator serta salah satu sumber belajar bagi siswa. Pada saat praktik siswa diwajibkan menggunakan seragam praktik sesuai dengan ketentuan sekolah. Memberikan refleksi terhadap semua pembelajaran siswa yang belum mampu mencapai kriteria yang telah ditentukan, sehingga akan mendorong kemampuan belajar siswa secara maksimal.

Karena hasil ketuntasan klasikal pada siklus I belum mencapai target yang diharapkan yaitu sebesar $85 \%$, maka penelitian ini dilanjutkan ke siklus II dengan melakukan perbaikan-perbaikan pembelajaran yang sesuai dengan kendala-kendala yang dihapi pada siklus I. Setelah diberikan tindakan pada siklus II, memberikan hasil peningkatan hasil belajar yang cukup signifikan. Adapun peningkatan rata-rata hasil belajar siswa pada akhir siklus II diperoleh sebesar 87,0 dengan ketuntasan klasikal sebesar $87,5 \%$.

Dari penjelasan di atas secara umum telah mampu menjawab rumusan masalah dan mencapai tujuan yang diharapkan peneliti. Penelitian ini dapat dikatakan berhasil karena semua kriteria yang ditentukan telah terpenuhi. $\mathrm{Hal}$ ini menandakan bahwa dengan penerapan metode pembelajaran Role Playing dapat meningkatkan hasil belajar Layanan Porter siswa kelas XI AP 1 semester genap tahun ajaran 2016/2017.

Keberhasilan dalam penelitian sesuai dengan teori-teori yang mendukung dalam proses pembelajaran keberhasilan dalam penelitian ini sesuai juga dengan yang dikemukakan oleh 1) Dita Tricandra Ningsih (2014) yang berjudul "Metode Role Playing Untuk Meningkatkan Aktivitas dan Hasil Belajar". Berdasarkan penelitian tindakan kelas melalui penerapan metode role playing pada siswa kelas IV Daud SD Muhammadiyah Metro Pusat dapat disimpulkan bahwa penerapan metode role playing dalam pembelajaran tematik dapat meningkatkan aktivitas belajar dan hasil belajar siswa. Nilai rata-rata aktivitas siswa pada siklus I 49.91 dan siklus II 76.30. Nilai rata-rata hasil belajar siswa siklus I 70.64 dan siklus II 82.75.

2) Emilda Amza dan Mawardi Effendi (2016) yang berjudul "Pengaruh Metode Pembelajaran Role Playing dan Motivasi Belajar Terhadap Hasil Belajar Menangani Dokumen Kantor SMK Negeri 1 Payakumbuh". Dari penelitian tersebut diperoleh hasil siswa yang melakukan pembelajaran dengan menggunakan metode role playing terbukti dari rata-rata hasil belajar mengelola dokumen kantor berbeda dengan siswa yang diajarkan dengan metode pemberian tugas. 4) I Gede Widiantara (2013) yang berjudul "Pengaruh Metode Pembelajaran Role Playing Berbantuan Media Audio-Visual Terhadap Keterampilan Berbicara Pelajaran Bahasa Indonesia Siswa Kelas V Desa Penglatan". Dari hasil penelitian, penerapan metode pembelajaran role 
playing berbantuan media audio-visual berpengaruh terhadap hasil keterampilan berbicara siswa kelas $V$ SD desa Penglatan Kecamatan Buleleng, Kabupaten Buleleng.

Dengan tercapainya semua kriteria yang telah ditentukan sebelumnya, maka penelitian tindakan kelas ini dihentikan.

Berdasarkan hasil penelitian tersebut, disarankan beberapa hal. Untuk siswa diharapkan agar menjadikan penerapan metode pembelajaran Role Playing ini sebagai pengalaman belajar yang bermakna. Untuk guru disarankan agar lebih mengoptimalkan pembelajaran dengan metode pembelajaran Role Playing agar dapat meningkatkan hasil belajar mata pelajaran Layanan Porter.

\section{SIMPULAN DAN SARAN}

Setelah melalui beberapa tahapan penerapan metode pembelajaran Role Playing, dan pelaksanaan dua siklus serta analisis data yang didapat, maka dapat ditarik simpulan (1)Penerapan metode pembelajaran role playing dapat meningkatkan hasil belajar siswa kelas XI AP 1 SMK Pariwisata Triatma Jaya pada mata pelajaran layanan porter. Hal ini ditunjukan dengan peningkatan hasil belajar pada siklus I dengan rata-rata 83,6 dan ketuntasan klasikal $62,5 \%$ dan pada siklus II terjadi peningkatan rata-rata sebesar 87,0 dengan ketuntasan klasikal $87,5 \%$. (2) Penerapan metode pembelajaran role playing memiliki respon yang positif pada siswa kelas XI AP 1 SMK Pariwisata Triatma Jaya pada mata pelajaran layanan porter. Dimana rata-rata respon siswa pada siklus I sebesar 58,03 dan pada siklus II menunjukan rata-rata siswa secara klasikal sebesar 64,18 yang berada dalam kategori positif.

\section{DAFTAR PUSTAKA}

Amza, Emilda, dkk (2016). "Pengaruh Metode Pembelajaran Role Playing dan Motivasi Belajar Terhadap Hasil Belajar Menangani Dokumen Kantor SMK Negeri 1 Payakumbuh". Jurnal IImiah Pendidikan. Volume 2, Nomor 1.

Hidayati. 2004. Pendidikan IImu Pengetahuan Sosial di Sekolah Dasar. Yogyakarta: FIP UNY

Ketut Jesiani. 2015 "Penerapan Metode Pembelajaran Role Playing Untuk Meningkatkan Aktivitas dan Hasil Belajar IPS Siswa Kelas VIII Di SMP Negeri 1 Banjar, Buleleng, Bali Tahun Ajaran 2014/2015" Journal Pendidikan Sejarah, Volume 3, No 1

Mulyasa. 2009. Praktik Penelitian Tindakan Kelas. Bandung : PT Remaja Rosdakarya Offset

Ningsih, Dita Tricandria, dkk (2014). "Metode Role Playing untuk Meningkatkan Aktivitas dan Hasil Belajar". Mimbar Pendidikan, Volume 21, No 10.

Nurkancana dan Sunartana. 1992. Evaluasi Hasil Belajar. Surabaya: Usaha Nasional.

Sudjana, Nana. 2004. Penilaian Hasil Proses Belajar Mengajar. Bandung: PT Remaja Rosdakarya 